\title{
Impact of Waste Heat Recovery of Chimney Using U-Shaped Pulsating Heat Pipe to Generate Hot Water- Experimental and Environmental Analysis
}

\author{
Shahin Shoeibi \\ Semnan University \\ Hadi Kargarsharifabad \\ Semnan University \\ Mohammad Mehdi Rashidi ( $\sim$ mm_rashidi@yahoo.com ) \\ University of Electronic Science and Technology of China https://orcid.org/0000-0002-6309-8688
}

\section{Research Article}

Keywords: Heat exchanger, Heat recovery, Heat pipe, Pulsating heat pipe.

Posted Date: December 30th, 2021

DOI: https://doi.org/10.21203/rs.3.rs-1125276/v1

License: () (1) This work is licensed under a Creative Commons Attribution 4.0 International License. Read Full License 


\section{Abstract}

Many studies have been done on the Pulsating heat pipes (PHP) using energy applications system. In this study a heat exchanger PHP is analyzed. A heat pipe prototype is manufactured for waste heat recovery. The present study experimentally investigated the effect of pulsating heat pipe on the waste heat recovery of the chimney and produce hot water for household consumption. The evaporator is placed in a smoke exhaust duct and the condenser is located in a water chamber in which the smoke heat is transferred through. The results are presented for different heat pipe angles to the horizon from 0 to 90 . The PHP is filled $60 \%$ by distilled water as operating fluid. The highest hot water temperature in outlet of reservoir was about to 58

${ }^{\circ} \mathrm{C}$. Also, The $\mathrm{CO}_{2}$ mitigation and $\mathrm{CPH}$ of the waste heat recovery system was equal to 84.82 tons and $0.1 \$ / \mathrm{m}^{3}$. Moreover, the efficiency is changing from $19 \%$ for a horizontal PHP to $54 \%$ for a vertical one.

\section{Introduction}

Heat pipes are effective instruments in the heat transfer of different energy applications (Guo et al. 2022, Jung \&Boo 2021). The heat pipe used in solar desalination (Fallahzadeh et al. 2020, Khalilmoghadam et al. 2021, Rastegar et al. 2020) to enhance the drinking water productivity, in thermoelectric generator (Date et al. 2014, Makki et al. 2016) to produce electrical, in photovoltaic thermal system (Jouhara et al. 2021, Zhang et al. 2021) to use from waste heat recovery of the system, and in HVAC system (Sukarno et al. 2021) to use energy recovery of the device. The heat transfer coefficient in the evaporator and condenser is significantly high and therefore the heat pipe is widely used in energy systems. As the thermal resistance of heat pipes is too low, it causes heat exchanger to have a smaller area and less mass compared to other traditional heat exchanger types. The use of pulsating heat pipes (PHP) is broadly extended to the vast variety of industrial sciences such as air preheater PHPs in thermal power plants, heat recovery from exhaust smoke and even electronic components cooling.

The pulsating heat pipe has a significant effect on solar energy applications. Xu et al. (Xu et al. 2020) numerically studied the thermal performance of compound parabolic concentrator solar collector using pulsating heat pipe. They found that the highest thermal efficiency of the system was about 74.5\%. Kargarsharifabad et al. (Kargar Sharif Abad et al. 2013) improved the freshwater generation of solar desalination system with a pulsating heat pipe. The obtained outcomes revealed that the highest productivity of modified solar desalination was about $875 \mathrm{ml} / \mathrm{m}^{2} \mathrm{hr}$. Also, the optimum water height in the solar desalination was equal to $0.01 \mathrm{~m}$. Aref et al. (Aref et al. 2021a) evaluated the effect of closed-loop pulsating heat pipe on water generation of humidification/dehumidification desalination. The outlet air from the dehumidifier was preheated and prehumidified by closed-loop pulsating heat pipe before entering the humidifier of the desalination system. They found that the highest daily freshwater generation of humidification/dehumidification desalination was about $8.7 \mathrm{~L} / \mathrm{m}^{2}$. Xu et al. (Xu et al. 2017) evaluated the impact of compound parabolic concentrator (CPC) and PHP on performance of solar collector. The CPC has a significantly enhance the intensity of solar radiation to the PHP as an absorber and also decrease the heat loss due to reduce in area of the hot zone. They showed that the highest energy efficiency of solar collector using CPC and PHP was about $50 \%$. Aref et al. (Aref et al. 2021b) investigated the effect of filling ration, inclination angle and solar intensity on performance of the novel closed-loop pulsating heat pipe. A flat plate collector was coupled with dual-diameter of pulsating heat pipe. The pulsating heat pipe was made of copper. The obtained results indicated that the highest efficiency of the solar collector with a filling ration of $60 \%$ was about $72.4 \%$. Alizadeh et al. (Alizadeh et al. 2020) improved the performance of photovoltaic system with using closed-loop PHP. The PHP was used to cool the photovoltaic module and also increase the electrical efficiency of the PV panel. The outcomes indicated that the improvement performance of the system with PHP was increased about $35 \%$. Alizadeh et al. (Alizadeh et al. 2018) increased the electrical performance of photovoltaic module using pulsating heat pipe. The results indicated that the power generation of photovoltaic module using pulsating heat pipe as a cooling system was enhanced about $18 \%$ compared with conventional photovoltaic module. The effect of very long PHP on performance of the solar water heater was studied by Arab et al. (Arab et al. 2012). The PHP was made of copper pipes with internal diameters of $2 \mathrm{~mm}$. They reported that the thermal efficiency of the thermosyphon mode of solar water heater using very long PHP was about 36\%. Chen et al. (Chen et al. 2020) studied the performance of the solar collector using flower type pulsating heat pipe. The acetone used as a working fluid in pulsating heat pipe. The results revealed that the thermal efficiency of system with filling ration of $50 \%$ was equal to $50 \%$.

Page 2/19 
A pulsating heat pipe was used in waste heat recovery system. Deng et al. (Deng et al. 2017) experimentally investigated the thermal performance of the anti-gravity pulsating heat pipe and heat recovery of the system. Their results revealed that the optimum filling ratio of the pulsating heat pipe was about $70 \%$. Also, the system was assisted to use the waste heat recovery to preheat the fuel oil. Li et al. (Li et al. 2020) studied the performance of pulsating heat pipe in low temperature heat recovery using graphene nanofluid. They reported that the thermal resistance amount reduces by raising the volume fraction of the graphene nanoparticles and also with raising the thermal load to the evaporator. An end closed one PHP which is used as an air preheater has been studied by Rittidech et al. (Rittidech et al. 2005). This PHP consists of an evaporator, an adiabatic part and a condenser. The $2 \mathrm{~mm}$ internal diameter heat pipe is made of copper. Water and R-123 are used as operating fluids. It is shown that any increase in temperature, causes the efficiency to increase. Also, the system operation will increase if R-123 is used instead of water. A preheater end closed PHP with one-way valve was fabricated by Meena et al. R-134a with a 50\% filling ratio was used as an operating fluid. Any increase in the hot air velocity and temperature would reduce the efficiency. Also this system has the capability to reduce the humidity from $80-100 \%$ to $54-72 \%$ (Meena et al. 2007). In another research, studied by Nuntaphan et al. (Nuntaphan et al. 2010), a heat exchanger is made of some PHPs. Hot water and air are used in this heat exchanger. The PHP is filled by methanol, Acetone and R-123. The results show that if the PHPs are used as fins, the heat transfer rate will be increased by 10\%. Mahajan et al (Mahajan et al. 2020) investigated the performance of the finned and bare tube oscillating heat pipe for waste heat recovery application. The results revealed that the average waste heat recovery of the finned oscillating heat pipe was about $80 \%$ higher than bare tube oscillating heat pipe at the same filling ration. Khodami et al. (Khodami et al. 2016) evaluated the effect of PHP used to waste heat recovery of the chimney. They showed that the exergy of the system using silver nanofluid is much better that ethanol as working fluid and also increased the exergy efficiency about $3 \%$. Dhone and Pise (Dhone \&Pise 2021) investigated the effect of waste heat recovery of the diesel generator using pulsating heat pipe. The different filling ratio of working fluid was used in pulsation heat pipe. The results showed that the optimum filling ratio of pulsating heat pipe on waste heat recovery was equal to $50 \%$.

The couple of PHP by energy applications can have high impact on the performance of these systems. The pulsating heat pipe used to reduce the heat loss of the system and also recovery of the waste heat. To our best knowledge, the PHP is not used for waste heat recovery of the chimney and use this thermal energy for increase water temperature. In this present study, the effect of pulsating heat pipe on the waste heat recovery of the chimney and produce hot water for household consumption is experimentally investigated. Also, the $\mathrm{CO}_{2}$ mitigation, economic analysis and environmental parameters was studied to assess the performance of the waste heat recovery system with PHP.

\section{Experimental Procedure}

\subsection{Experimental setup}

The heat exchanger consists of three main parts includes the pulsating heat pipe, exhaust air channel from chimney and water reservoir for produce hot water. The PHP is fabricated by using copper pipes with suitable internal diameter of $0.002 \mathrm{~m}$. The rolling around a $0.02 \mathrm{~m}$ shaft, the $0.002 \mathrm{~m}$ copper pipe turns to $21 \mathrm{U}$ shape ones in only $1 \mathrm{~m}$ distance. The pipe firstly is evacuated to the $175 \mathrm{~Pa}$ and then filled with distilled water up to $60 \%$ filling ratio. Fig. 1 shows the fabricated pulsating heat pipe.

The exhaust air channel was made of galvanized sheet where the evaporation part of the PHP is placed with dimensions of $100 \times 0.55 \times 0.05 \mathrm{~m}$ with a sheet thickness of $0.0005 \mathrm{~m}$. The heat exchangers are used to seal internal and external connections of the channel, as shown in Fig. 2. The evaporators of PHPs are installed through the channel.

The water reservoir was made of galvanized plate with dimensions of $100 \times 0.55 \times 0.05 \mathrm{~m}$ and a 0.003 plate thickness. The condensers of PHPs (U shaped pipes) are installed through the reservoir and the connections are sealed by welding and silicone adhesive. Fig. 3 indicates water reservoir and installed pulsating heat pipe in it. A thin sheet of aluminum is used for keeping the adhesives away from sunlight. To decrease the heat loss, the parts of the PHPs which are neither in channel nor in reservoir, are covered by asbestos yarn. 
The test setup was installed in which the exhaust air goes through the channel for heat exchanging (PHPs) in a constant temperature $180^{\circ} \mathrm{C}$, and then it leaves to the atmosphere in a temperature near $108^{\circ} \mathrm{C}$. In this experiment exhaust air is the air produced by household devices. Fig. 4 shows the test setup of waste heat recovery system using pulsating heat pipe. The water reservoir has an inlet at the bottom and an outlet at the top. Household water is used to be heated. Actually in this setup a heat exchanger for indoor use is described. Temperatures are measured by 5 sensors, a thermometer and a key selector to switch between sensors. The sensors are installed at reservoirs inlet and outlet, channel inlet and outlet, and heat pipes. The water flow is measured by a 10-100 L/h rotameter. The water flow rate of water reservoir was considered equal to $30 \mathrm{~L} / \mathrm{h}$ and air exhaust velocity from chimney was equal to $0.7 \mathrm{~m} / \mathrm{s}$. An anemometer is used for air velocity measurement. Fig. 5 illustrates the schematic of pulsating heat pipe.

\subsection{Uncertainty of results}

Uncertainty evaluating of test measuring data was investigated. The value of uncertainty is achieved by data sheet of the devices and some by the builder and is calculated by (Shoeibi et al. 2020):

$$
\{u\}=\backslash \text { frac }\{\{a\}\}\{\backslash \text { sqrt }\{3\}\} \quad(1)
$$

Where a and $u$ represent the standard uncertainty and accuracy of equipment. Table 1 illustrates the uncertainty of the measuring device.

Table 1

Uncertainty of devices

\begin{tabular}{|llll|}
\hline Devices & Accuracy & Range & uncertainty \\
\hline Thermometer $\left({ }^{\circ} \mathrm{C}\right)$ & 0.1 & $-100-1300$ & 0.06 \\
\hline Rotameter $(\mathrm{L} / \mathrm{h})$ & 0.1 & $0-100$ & 0.06 \\
\hline Anemometer $(\mathrm{m} / \mathrm{s})$ & 0.5 & $0-30$ & 0.3 \\
\hline
\end{tabular}

\section{Theoretical Background}

\subsection{Thermal efficiency}

The energy efficiency of the system is defined as thermal energy produce for raising the water temperature to the heat energy inlet from exhaust air of chimney and is calculated as follow:

$\backslash$ eta $=\backslash f \operatorname{rac}\left\{\{\backslash \operatorname{dot}\{Q\}\}_{-}\{w\}\right\}\left\{\{\operatorname{dot}\{Q\}\}_{-}\{a\}\right\}$

2

Where $\{\backslash \operatorname{dot}\{\backslash \operatorname{text}\{Q\}\}\}_{-}\{\mid \operatorname{text}\{w\}\}$ and $\{\backslash \operatorname{dot}\{\backslash \operatorname{text}\{Q\}\}\}_{-}\{\mid \operatorname{text}\{a\}\}$ are the thermal energy produce in water and thermal energy inlet to the system, respectively. The main heat transfer mechanisms in PHPs are sensible heat transfer and phase change. The sensible heat transfer is due to fluid and vapor movement through the pipe causing heat to be transferred from evaporator to condenser. It can be easily shown that the amount of heat transfer to the water from exhaust air of chimney and is obtained by:

$\{\backslash \operatorname{dot}\{\backslash \operatorname{text}\{Q\}\}\}_{-}\{\mid \operatorname{text}\{w\}\}=\{\backslash \operatorname{dot}\{\backslash \operatorname{text}\{m\}\}\}_{-}\{\backslash \operatorname{text}\{w\}\}\{\backslash \operatorname{text}\{C\}\}_{-}\left\{\backslash \operatorname{text}\{p\}_{,} \operatorname{text}\{w\}\right\} \backslash \operatorname{left}\left(\{\backslash \operatorname{text}\{T\}\}_{-}\left\{\backslash \operatorname{text}\{w\}_{,}, \operatorname{text}\{0\}\right\}_{-}\right.$ $\{\backslash \operatorname{text}\{T\}\}_{-}\{\backslash$ text $\{W\}, \mid$ text $\{i\}\} \backslash$ right $)$

3

where $\{\backslash \operatorname{dot}\{\backslash \operatorname{text}\{m\}\}\}_{-}\{\backslash \operatorname{text}\{w\}\},\{\backslash \operatorname{text}\{T\}\}_{-}\{\backslash \operatorname{text}\{w\}, \mid \operatorname{text}\{0\}\}$ and $\{\backslash \operatorname{text}\{T\}\}_{-}\{\backslash \operatorname{text}\{w\}, \mid$ text $\{i\}\}$ show the mass flow rate of the water, water temperature inlet and oulet, respectively. Similarly, the amount of waste heat leaves exhaust air is shown by:

$\{\mid \operatorname{dot}\{\backslash \operatorname{text}\{Q\}\}\}_{-}\{\backslash \operatorname{text}\{a\}\}=\{\backslash \operatorname{dot}\{\backslash \operatorname{text}\{m\}\}\}_{-}\{\mid \operatorname{text}\{a\}\}\{\backslash \operatorname{text}\{C\}\}_{-}\{|\operatorname{text}\{p\},| \operatorname{text}\{a\}\} \backslash \mid \operatorname{eft}\left(\{\backslash \operatorname{text}\{T\}\}_{-}\left\{\mid \operatorname{text}\{a\}_{,}, \operatorname{text}\{i\}\right\}_{-}\right.$ $\{\backslash \operatorname{text}\{T\}\}_{-}\{\backslash \operatorname{text}\{a\}, \backslash \operatorname{text}\{0\}\} \backslash$ right $)$ 
where $\{\backslash \operatorname{dot}\{\backslash \operatorname{text}\{m\}\}\}_{-}\{\backslash \operatorname{text}\{a\}\},\{\mid \operatorname{text}\{T\}\}_{-}\{\backslash \operatorname{text}\{w\}, \mid \operatorname{text}\{0\}\}$ and $\{\backslash \operatorname{text}\{T\}\}_{-}\{\backslash \operatorname{text}\{a\}, \backslash \operatorname{text}\{i\}\}$ represent the mass flow rate of the water, temperature outlet and inlet air, respectively. Consequently, efficiency of the heat exchanger is shown as follows:

$\{$ leta $\}=\backslash \operatorname{frac}\left\{\{\backslash \operatorname{dot}\{\backslash \operatorname{text}\{\operatorname{m}\}\}\}_{-}\{\backslash \operatorname{text}\{w\}\}\{\operatorname{text}\{C\}\}_{-}\{\backslash \operatorname{text}\{p\}, \mid \operatorname{text}\{w\}\} \backslash \operatorname{left}\left(\{\backslash \operatorname{text}\{T\}\}_{-}\{|\operatorname{text}\{w\},| \operatorname{text}\{0\}\}-\right.\right.$ $\left.\left.\{\backslash \operatorname{text}\{T\}\}_{-}\{\mid \operatorname{text}\{w\}, \backslash \operatorname{text}\{i\}\} \backslash \operatorname{right}\right)\right\}\{\backslash \operatorname{dot}\{\backslash \operatorname{text}\{m\}\}\}_{-}\{\backslash \operatorname{text}\{a\}\}\{\backslash \operatorname{text}\{C\}\}_{-}\{\backslash \operatorname{text}\{\mathrm{p}\}, \backslash \operatorname{text}\{a\}\} \backslash \operatorname{left}\left(\{\backslash \operatorname{text}\{T\}\}_{-}\{|\operatorname{text}\{a\},| \operatorname{text}\{i\}\}-\right.$ $\{\backslash \operatorname{text}\{T\}\} \_\{\backslash \text { text }\{a\}, \backslash \text { text }\{0\}\} \backslash$ right $\left.)\right\}$

5

If there was no heat loss in the system, the efficiency would be equal to one, but the heat loss affects directly on the efficiency reduction.

\subsection{Price of hot water generation}

The price per liter of hot water generation was assessed to cost effective of the fabrication of the waste heat recovery application using pulsating heat pipe. The capital recovery coefficient is used for economic evaluation, which defines the achievement of the investment and is defined by the ratio of a fixed annuity to the value of obtaining that annuity for a specific duration of time and is calculated by (Shoeibi et al. 2021e):

Imathbf $\{C\} \backslash$ mathbf $\{R\} \backslash$ mathbf $\{F\}=\backslash$ frac $\left\{\backslash\right.$ mathbf $\left.\{i\}\{(1+\backslash \operatorname{mathbf}\{i\})\}^{\wedge}\{\backslash \operatorname{mathbf}\{n\}\}\right\}$

$\left\{\{\backslash \text { left }(1+\backslash \text { mathbf }\{i\} \backslash \text { right })\}^{\wedge}\{\backslash\right.$ mathbf $\left.\{n\}\}-1\right\}$

where $i$ and $n$ depict the interest rate of a bank loan (20\% in this paper) and the lifespan of waste heat recovery system, which is assumed to be twenty years. The first annual cost is shown as follow (Shoeibi et al. 2021c):

$\backslash$ mathbf $\{F\} \backslash$ mathbf $\{A\} \backslash$ mathbf $\{C\}=\backslash$ mathbf $\{P\} \backslash$ times $\backslash$ mathbf $\{C\} \backslash$ mathbf $\{R\} \backslash$ mathbf $\{F\}$

where P shows the capital price of waste heat recovery application. The annual salvage value is determined as the value of the goods of waste heat recovery system and is calculated by (Shoeibi et al. 2021d):

$\backslash$ mathbf $\{A\} \backslash$ mathbf $\{S\} \backslash$ mathbf $\{\bigvee\}=\backslash$ mathbf $\{S\} \backslash$ times $\backslash$ mathbf $\{S\} \backslash$ mathbf $\{S\} \backslash$ mathbf $\{F\}$

where $S$ is the salvage amount of waste heat recovery system and is about $20 \%$ of the used all goods value of the system. The sinking fund factor is obtained by (Shoeibi et al. 2021b):

$\backslash$ mathbf $\{S\} \backslash$ mathbf $\{F\} \backslash$ mathbf $\{F\}=\backslash$ frac $\{\backslash$ mathbf $\{i\}\}\left\{\{\backslash \operatorname{left}(1+\backslash \text { mathbf }\{i\} \backslash \text { right })\}^{\wedge}\{\backslash \operatorname{mathbf}\{\right.$ n $\left.\}\}-1\right\}$

The annual maintenance costs such as the annual cost of maintenance of the system, which is assumed to value for ten percentage of the FAC and obtained by (Shoeibi et al. 2021a):

$\backslash$ mathbf $\{A\} \backslash$ mathbf $\{M\} \backslash$ mathbf $\{C\}=0.10 \backslash$ times $\backslash$ mathbf $\{F\} \backslash$ mathbf $\{A\} \backslash$ mathbf $\{C\}$

The uniform annual price of the application is obtained as follow:

$\backslash$ mathbf $\{U\} \backslash$ mathbf $\{A\} \backslash$ mathbf $\{P\}=\backslash$ mathbf $\{F\} \backslash$ mathbf $\{A\} \backslash$ mathbf $\{C\}+\backslash$ mathbf $\{A\} \backslash$ mathbf $\{M\} \backslash$ mathbf $\{C\}-$ $\backslash$ mathbf $\{A\} \backslash$ mathbf $\{S\} \backslash \operatorname{mathbf}\{\bigvee\}$

The cost per cubic meter of hot water generation is determined as the ratio of the UAP to the annual hot water generation (HW) of the system and is achieved by (Shoeibi et al. 2021d):

$\backslash$ mathbf $\{C\} \backslash$ mathbf $\{P\} \backslash$ mathbf $\{H\}=\backslash f r a c\{\backslash$ mathbf $\{U\} \backslash$ mathbf $\{A\} \backslash$ mathbf $\{C\}\} \backslash$ mathbf $\{H\} \backslash$ mathbf $\{W\}\}$

\section{3. $\mathrm{CO}_{2}$ mitigation}

The annual $\mathrm{CO}_{2}$ mitigation in the waste heat recovery system is calculated as

$\left\{\left\{(\backslash \operatorname{text}\{E\}\}_{-}\{\backslash \operatorname{text}\{\operatorname{e}\} \backslash \operatorname{text}\{n\}\}\right)\right\}_{-}\{\mid \operatorname{text}\{0\} \backslash \operatorname{text}\{\mathrm{u}\} \backslash \operatorname{text}\{t\}\} \times 2$ and the $\mathrm{CO}_{2}$ removal in the period of lifespan is determined as 
$\left\{\left\{(\backslash \operatorname{text}\{E\}\}_{-}\{\mid \operatorname{text}\{e\} \backslash \operatorname{text}\{n\}\}\right)\right\}_{-}\{\mid \operatorname{text}\{0\} \backslash \operatorname{text}\{\mathrm{u}\} \backslash$ text $\{\mathrm{t}\}\} \times 2 \times y e a r$. The value of $\mathrm{CO}_{2}$ removal in the period of lifespan is achieved as follow (Joshi \&Tiwari 2018):

$\{\{\backslash \text { phi }\}\}_{-}\left\{\backslash\right.$ mathbf $\left.\{c\}\{\backslash \operatorname{mathbf}\{0\}\}_{-}\{2\}\right\}=\backslash$ frac $\{\{\{\{2$

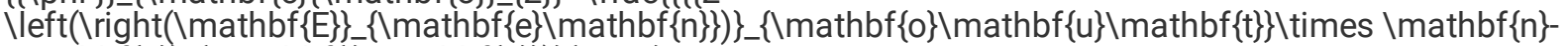

$\backslash$ mathbf $\{E\}\}_{-}\{$mathbf $\{i\} \backslash$ mathbf $\{$ n $\left.\left.\}\}\right)\right\}\{1000\}$

\subsection{Enviroeconomic parameter}

The enviroeconomic parameter is specified as the price achieved by the $\mathrm{CO}_{2}$ reduction in the period of lifespan of the waste heat recovery system and is achieved by:

$\left.\{\backslash \text { mathbf }\{Z\}\}_{-}\left\{\backslash \operatorname{mathbf}\{c\}\{\backslash \operatorname{mathbf}\{0\}\}_{-}\{2\}\right\}=\{\backslash \operatorname{mathbf}\{Z\}\}_{-}\{\text {mathbf }\{c\} \backslash \text { mathbf }\{0\}\}_{-}\{2\}\right\} \backslash$ times $\{\{\backslash \text { phi }\}\}_{-}\{\backslash \operatorname{mathbf}\{c\}$ $\left.\{\mid \operatorname{mathbf}\{0\}\}_{-}\{2\}\right\}$

The cost of $\mathrm{CO}_{2}$ is about $14.5 \$$ per ton (Parsa et al. 2020).

\section{Results And Discussion}

In this study, the inlet and outlet air exhaust temperatures from chimney, the inlet and outlet water temperature from water reservoir, and thermal efficiency of the waste heat recovery application. The experimental study was used to assess the performance of the waste heat recovery application using pulsating heat pipe to produce hot water. Furthermore, cost of one cubic meter of hot water generation $(\mathrm{CPH})$, and environmental analysis of waste heat recovery system are presented and discussed. The different angles of the pulsating heat pipe was tested to optimized best angle of heat pipe. Each experiment is done four times to reduce the errors. With respect to the annual measuring of energy produce and hot water, the data of the one-day experiment (December 2, 2020) were applied to all days of the year. Fig. 6 shows the inlet and outlet temperature of the air exhaust from chimney. The outcomes revealed that the lowest temperature of outlet air temperature from channel was obtained at angle of 90 degrees, which was equal to $105.1^{\circ} \mathrm{C}$. Also, the amount of inlet air temperature in channel was the same at different and was equal to $180^{\circ} \mathrm{C}$. Moreover, the angle of the pulsating heat pipe has an inverse effect to air outlet temperature of channel due to increasing the heat transfer rate between air exhaust and water reservoir.

Figure 7 depicts the temperature of inlet and outlet water of the hot water reservoir. The results showed that the maximum hot water temperature in outlet of reservoir was achieved at angle of 90 degrees, which was about to $58^{\circ} \mathrm{C}$. Also, the amount of inlet water temperature in reservoir was about $33^{\circ} \mathrm{C}$. Moreover, the angle of the pulsating heat pipe has a direct impact to hot water outlet temperature of reservoir due to enhance in heat transfer rate between an air exhaust and water reservoir.

Figure 8 indicates the energy efficiency and pulsating heat pipe temperature of the waste heat recovery system. As observed, the highest energy efficiency and pulsating heat pipe temperature was achieved in angle of 90 degrees, which were equal to $54 \%$ and $80^{\circ} \mathrm{C}$, respectively. By increasing the evaporator surface temperature of PHP, the thermal efficiency of the application increased due to increasing the heat transfer between water and heat pipes. Also, the lowest energy efficiency was about $19 \%$ which was occurred in angle of 0 degrees.

Figure 9 illustrates the energies of hot water, air exhaust and waste heat energy from the system. The obtained outcomes showed that as the energy of hot water raised, the energy of air exhaust decreasing due to high heat transfer between heat pipes and water. The highest energy of hot water was equal to $872 \mathrm{~W}$ which was occurred in angle of 90 degrees. Also, the waste heat energy of the system was increased by increasing the angle of the PHP. The highest waste heat energy of the system was occurred in angle of 0 degree, which was about $1303 \mathrm{~W}$.

Table 2 provides the price of fabrication of the waste heat recovery system. The results revealed that the price of fabrication and salvage value of the waste heat recovery system are about $117 \$$ and $23.4 \$$, respectively. Table 3 depicts the price of one 
cubic meter of hot water production with using waste heat recovery system. The results indicated that the annual hot water generation and $\mathrm{CPH}$ of the system were equal to $262.8 \mathrm{~m}^{3} /$ year and $0.1 \$ / \mathrm{m}^{3}$, respectively.

Table 2

Cost of fabricated of waste heat recovery application using pulsating heat pipe

\begin{tabular}{|lll|}
\hline Waste heat recovery system components & Cost of system (\$) & Salvage value (\$) \\
\hline Galvanized body of channel & 35 & 7 \\
\hline Pipes of air exhaust & 10 & 2 \\
\hline Galvanized support & 12 & 2 \\
\hline Pulsating heat pipe & 30 & 6 \\
\hline Water reservoir & 20 & 4 \\
\hline Aluminum sheet & 10 & 2 \\
\hline Total cost & 117 & 23.4 \\
\hline
\end{tabular}

Table 3

Economic analysis of waste heat recovery system

\begin{tabular}{|c|c|c|c|c|c|c|c|c|c|c|c|}
\hline Type & $\begin{array}{l}\mathrm{n} \\
\text { (year) }\end{array}$ & $\begin{array}{l}i \\
(\%)\end{array}$ & CRF & $\begin{array}{l}\text { FAC } \\
\text { (\$/year) }\end{array}$ & SFF & $\begin{array}{l}S \\
(\$)\end{array}$ & $\begin{array}{l}\text { ASV } \\
\text { (\$/year) }\end{array}$ & $\begin{array}{l}\text { AMC } \\
\text { (\$/year) }\end{array}$ & $\begin{array}{l}\text { UAP } \\
\text { (\$/year) }\end{array}$ & $\begin{array}{l}M \\
\text { (m³/year) }\end{array}$ & $\begin{array}{l}\mathrm{CPH} \\
\left(\$ / \mathrm{m}^{3}\right.\end{array}$ \\
\hline $\begin{array}{l}\text { Waste } \\
\text { heat } \\
\text { recovery }\end{array}$ & 20 & 0.2 & 0.205 & 24.03 & 0.005 & 23.4 & 0.125 & 2.4 & 26.3 & 262.8 & 0.10 \\
\hline
\end{tabular}

Table 4 presents the embodied energy to generate various goods and material used in the application using PHP for generate hot water. The embodied energy of the waste heat recovery system was about $439.7 \mathrm{kWh}$. 
Table 4

Embodied energy of different material of waste heat recovery application

\begin{tabular}{|c|c|c|c|c|c|}
\hline \multirow[t]{2}{*}{ Type } & \multirow{2}{*}{$\begin{array}{l}\text { Name of } \\
\text { material }\end{array}$} & \multicolumn{2}{|c|}{ Energy density } & \multirow{2}{*}{$\begin{array}{l}\text { Weight of } \\
\text { component } \\
\text { (kg) }\end{array}$} & \multirow{2}{*}{ 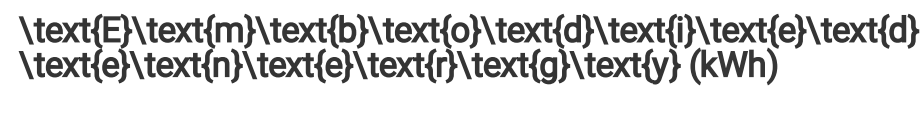 } \\
\hline & & $\mathrm{MJ} / \mathrm{kg}$ & $\mathrm{kWh} / \mathrm{kg}$ & & \\
\hline \multicolumn{6}{|c|}{$\begin{array}{l}\text { Waste } \\
\text { heat } \\
\text { recovery } \\
\text { system }\end{array}$} \\
\hline & $\begin{array}{l}\text { Aluminum } \\
\text { sheet }\end{array}$ & 199 & 55.2 & 1.3 & 71.8 \\
\hline & $\begin{array}{l}\text { Galvanized } \\
\text { body of } \\
\text { channel }\end{array}$ & 50 & 13.9 & 3.5 & 48.6 \\
\hline & $\begin{array}{l}\text { Galvanized } \\
\text { body of } \\
\text { reservoir }\end{array}$ & 50 & 13.9 & 8 & 111.2 \\
\hline & $\begin{array}{l}\text { Copper } \\
\text { pulsating } \\
\text { heat pipe }\end{array}$ & 100 & 27.7 & 4 & 110.8 \\
\hline & $\begin{array}{l}\text { Support } \\
\text { (Galvanized) }\end{array}$ & 50 & 13.9 & 7 & 97.3 \\
\hline & $\begin{array}{l}\text { Total } \\
\text { Embodied } \\
\text { energy } \\
\text { (kWh) }\end{array}$ & - & - & - & 439.7 \\
\hline
\end{tabular}

Table 5 shows the environmental, enviroeconomic parameters in the waste heat recovery system for a lifespan of 20 years. The results indicated that the $\mathrm{CO}_{2}$ reduction and enviroeconomic parameter of waste heat recovery application were equal to 84.82 tons and $1217.2 \$$, respectively, during life time. Also, the $\mathrm{CO}_{2}$ emission of the waste heat recovery system during life time based on embodied energy was equal to $879.4 \mathrm{~kg}$.

Table 5

Environmental and enviroeconomic parameter for waste heat recovery system

\begin{tabular}{|ll|}
\hline Parameter & Waste heat recovery system \\
\hline Life time (years) & 20 \\
\hline Embodied Energy $(\mathrm{kWh})$ & 439.7 \\
\hline Annual energy produce by waste heat recovery (kWh/year) & 2120.6 \\
\hline $\mathrm{CO}_{2}$ emission during life time $(\mathrm{kg})$ & 879.4 \\
\hline $\mathrm{CO}_{2}$ mitigation during life time (ton) & 84.82 \\
\hline Environmental parameter (ton $\left.\{\backslash \operatorname{text}\{\mathrm{C}\} \backslash \text { text }\{0\}\}_{-}\{2\}\right)$ & 83.94 \\
\hline Enviroeconomic parameter $(\$)$ & 1217.2 \\
\hline
\end{tabular}

\section{Conclusion}

In this research a novel application of PHPs in heat exchangers are reviewed and experimentally tested. The results show that this prototype of heat exchanger that is working by PHPs can reach an efficiency up to $54 \%$ which is noticeable. This type of heat exchanger is applicable in any place that hot air and cold water do exist. In many industries, hot exhaust air produced by 
industrial instruments is easily left to atmosphere which can simply affects unwanted global warming. If such a heat exchanger were used on the exhaust air channel before leaving to the atmosphere, not only the heat could be easily be recovered, but also it would prevent the unwanted global warming. This type of heat exchanger can even be used as an appliance for such houses which use fossil fuel (such as oil or gas fuel) as the main resource for household heating. Exhaust air of heating devices can easily be used to get the household water hot. The main conclusion presented as follow:

- The $\mathrm{CO}_{2}$ mitigation and enviroeconomic parameter of waste heat recovery system were equal to 84.82 tons and $1217.2 \$$, respectively.

- The annual hot water generation and $\mathrm{CPH}$ of the system were equal to $262.8 \mathrm{~m}^{3} /$ year and $0.1 \$ / \mathrm{m}^{3}$, respectively.

- The price of fabrication of the waste heat recovery system was about $117 \$$.

- The highest energy of hot water was equal to $872 \mathrm{~W}$ which was occurred in angle of 90 degree.

- The highest energy efficiency and pulsating heat pipe temperature was achieved in angle of 90 degree, which were equal to $54 \%$ and $80^{\circ} \mathrm{C}$.

- The angle of the pulsating heat pipe has a direct impact to hot water outlet temperature of reservoir.

- The highest hot water temperature in outlet of reservoir was about to $58^{\circ} \mathrm{C}$.

\section{Abbreviations}

\begin{tabular}{|c|c|}
\hline AMC & Annual maintenance price $(\$)$ \\
\hline $\mathrm{CPH}$ & Cost per cubic meter of hot water $(\$)$ \\
\hline ASV & Annual salvage amount (\$) \\
\hline CRF & Capital recovery coefficient \\
\hline FAC & First annual cost $(\$)$ \\
\hline UAP & Uniform annual cost $(\$)$ \\
\hline $\mathrm{Z}_{\mathrm{CO} 2}$ & Enviroeconomic parameter $(\$)$ \\
\hline $\mathrm{z}_{\mathrm{CO} 2}$ & Carbon price (\$) \\
\hline$E_{\text {in }}$ & Embodied energy (kWh) \\
\hline HW & Annual hot water generation, ( $\mathrm{m}^{3} /$ year) \\
\hline$\{\mid \operatorname{dot}\{\backslash \operatorname{text}\{Q\}\}\}_{-}\{$text $\{w\}\}$ & Thermal energy of hot water, $\mathrm{W}$ \\
\hline$\{\mid \operatorname{dot}\{\backslash \operatorname{text}\{Q\}\}\} \_\{\mid \operatorname{text}\{a\}\}$ & Waste heat energy of the chimney, W \\
\hline $\mathrm{T}_{\mathrm{i}}$ & Inlet temperature, ${ }^{\circ} \mathrm{C}$ \\
\hline $\mathrm{T}_{\mathrm{O}}$ & Outlet temperature, ${ }^{\circ} \mathrm{C}$ \\
\hline \multirow[t]{2}{*}{ Ivarphi_\{CO2\}\} } & Environmental parameter (ton $\backslash$ mathbf $\{c\} \backslash$ mathbf $\{0\}\}_{-}\{2\}$ ) \\
\hline & Subscripts \\
\hline w & Water \\
\hline a & Air \\
\hline en & Energy \\
\hline
\end{tabular}

\section{Declarations}


Author contribution Shahin Shoeibi: Conceptualization, investigation, data curation, writing original draft, and editing.

Hadi Kargarsharifabad: Conceptualization, resources, performing experiments, formal analysis, writing-review and editing.

Mohammad Mehdi Rashidi: Conceptualization, writing-review and editing.

Data availability Data can be made available on request.

Ethics Approval Not applicable

Consent to Participate Not applicable

Consent for Publication Not applicable

Competing Interests The authors declare no competing interests.

Funding Not applicable

\section{References}

1. Alizadeh H, Ghasempour R, Shafii MB, Ahmadi MH, Yan W-M, Nazari MA (2018): Numerical simulation of PV cooling by using single turn pulsating heat pipe. International Journal of Heat and Mass Transfer 127, 203-208

2. Alizadeh H, Alhuyi Nazari M, Ghasempour R, Shafii MB, Akbarzadeh A (2020): Numerical analysis of photovoltaic solar panel cooling by a flat plate closed-loop pulsating heat pipe. Solar Energy 206, 455-463

3. Arab M, Soltanieh M, Shafii MB (2012): Experimental investigation of extra-long pulsating heat pipe application in solar water heaters. Experimental Thermal and Fluid Science 42, 6-15

4. Aref L, Fallahzadeh R, Madadi Avargani V (2021a): An experimental investigation on a portable bubble basin humidification/dehumidification desalination unit utilizing a closed-loop pulsating heat pipe. Energy Conversion and Management 228, 113694

5. Aref L, Fallahzadeh R, Shabanian SR, Hosseinzadeh M (2021b): A novel dual-diameter closed-loop pulsating heat pipe for a flat plate solar collector. Energy 230, 120751

6. Chen Y, He Y, Zhu X (2020): Flower-type pulsating heat pipe for a solar collector. International Journal of Energy Research $44,7734-7745$

7. Date A, Date A, Dixon C, Akbarzadeh A (2014): Theoretical and experimental study on heat pipe cooled thermoelectric generators with water heating using concentrated solar thermal energy. Solar Energy 105, 656-668

8. Deng Z, Zheng Y, Liu X, Zhu B, Chen Y (2017): Experimental study on thermal performance of an anti-gravity pulsating heat pipe and its application on heat recovery utilization. Applied Thermal Engineering 125, 1368-1378

9. Dhone SB, Pise A (2021): Waste Heat Recovery (WHR) of Diesel Engine Using Closed-Loop Pulsating Heat Pipe. Trends in Mechanical and Biomedical Design, 765-774

10. Fallahzadeh R, Aref L, Gholamiarjenaki N, Nonejad Z, Saghi M (2020): Experimental investigation of the effect of using water and ethanol as working fluid on the performance of pyramid-shaped solar still integrated with heat pipe solar collector. Solar Energy 207, 10-21

11. Guo C, Wang T, Guo C, Jiang Y, Tan S, Li Z (2022): Effects of filling ratio, geometry parameters and coolant temperature on the heat transfer performance of a wraparound heat pipe. Applied Thermal Engineering 200, 117724

12. Joshi P, Tiwari GN (2018): Energy matrices, exergo-economic and enviro-economic analysis of an active single slope solar still integrated with a heat exchanger: A comparative study. Desalination 443, 85-98

13. Jouhara H, Bertrand D, Axcell B, Montorsi L, Venturelli M, Almahmoud S, Milani M, Ahmad L, Chauhan A (2021): Investigation on a full-scale heat pipe heat exchanger in the ceramics industry for waste heat recovery. Energy 223, 120037

Page 10/19 
14. Jung EG, Boo JH (2021): Enhancement of the maximum heat transfer rate of the heat pipe through the bypass line. Applied Thermal Engineering 198, 117461

15. Kargar Sharif Abad H, Ghiasi M, Jahangiri Mamouri S, Shafii MB (2013): A novel integrated solar desalination system with a pulsating heat pipe. Desalination 311, 206-210

16. Khalilmoghadam P, Rajabi-Ghahnavieh A, Shafii MB (2021): A novel energy storage system for latent heat recovery in solar still using phase change material and pulsating heat pipe. Renewable Energy 163, 2115-2127

17. Khodami R, Abbas Nejad A, Ali Khabbaz MR (2016): Experimental investigation of energy and exergy efficiency of a pulsating heat pipe for chimney heat recovery. Sustainable Energy Technologies and Assessments 16, 11-17

18. Li Z, Sarafraz MM, Mazinani A, Moria H, Tlili I, Alkanhal TA, Goodarzi M, Safaei MR (2020): Operation analysis, response and performance evaluation of a pulsating heat pipe for low temperature heat recovery. Energy Conversion and Management 222, 113230

19. Mahajan G, Cho H, Smith A, Thompson SM (2020): Experimental Analysis of Atypically Long Finned Oscillating Heat Pipe for Ventilation Waste Heat Recovery Application. Journal of Thermal Science 29, 667-675

20. Makki A, Omer S, Su Y, Sabir H (2016): Numerical investigation of heat pipe-based photovoltaic-thermoelectric generator (HP-PV/TEG) hybrid system. Energy Conversion and Management 112, 274-287

21. Meena P, Rittidech S, Poomsa-ad N (2007): Application of closed-loop oscillating heat-pipe with check valves (CLOHP/CV) air-preheater for reduced relative-humidity in drying systems. Applied Energy 84, 553-564

22. Nuntaphan A, Vithayasai S, Vorayos N, Vorayos N, Kiatsiriroat T (2010): Use of oscillating heat pipe technique as extended surface in wire-on-tube heat exchanger for heat transfer enhancement. International Communications in Heat and Mass Transfer 37, 287-292

23. Parsa SM, Rahbar A, Javadi Y D, Koleini MH, Afrand M, Amidpour M (2020): Energy-matrices, exergy, economic, environmental, exergoeconomic, enviroeconomic, and heat transfer (6E/HT) analysis of two passive/active solar still water desalination nearly 4000m: Altitude concept. Journal of Cleaner Production, 121243

24. Rastegar S, Kargarsharifabad H, Rahbar N, Shafii MB (2020): Distilled water production with combination of solar still and thermosyphon heat pipe heat exchanger coupled with indirect water bath heater - Experimental study and thermoeconomic analysis. Applied Thermal Engineering 176, 115437

25. Rittidech S, Dangeton W, Soponronnarit S (2005): Closed-ended oscillating heat-pipe (CEOHP) air-preheater for energy thrift in a dryer. Applied Energy 81, 198-208

26. Shoeibi S, Rahbar N, Abedini Esfahlani A, Kargarsharifabad H (2020): Application of simultaneous thermoelectric cooling and heating to improve the performance of a solar still: An experimental study and exergy analysis. Applied Energy 263, 114581

27. Shoeibi S, Kargarsharifabad H, Mirjalily SAA, Zargarazad M (2021a): Performance analysis of finned photovoltaic/thermal solar air dryer with using a compound parabolic concentrator. Applied Energy 304, 117778

28. Shoeibi S, Kargarsharifabad H, Rahbar N (2021b): Effects of nano-enhanced phase change material and nano-coated on the performance of solar stills. Journal of Energy Storage 42, 103061

29. Shoeibi S, Rahbar N, Abedini Esfahlani A, Kargarsharifabad H (2021c): Improving the thermoelectric solar still performance by using nanofluids- Experimental study, thermodynamic modeling and energy matrices analysis. Sustainable Energy Technologies and Assessments 47, 101339

30. Shoeibi S, Rahbar N, Abedini Esfahlani A, Kargarsharifabad H (2021d): A comprehensive review of Enviro-Exergoeconomic analysis of solar stills. Renewable and Sustainable Energy Reviews 149, 111404

31. Shoeibi S, Rahbar N, Esfahlani AA, Kargarsharifabad H (2021e): Energy matrices, exergoeconomic and enviroeconomic analysis of air-cooled and water-cooled solar still: Experimental investigation and numerical simulation. Renewable Energy 171, 227-244

32. Sukarno R, Putra N, Hakim II (2021): Non-dimensional analysis for heat pipe characteristics in the heat pipe heat exchanger as energy recovery device in the HVAC systems. Thermal Science and Engineering Progress 26, 101122

Page $11 / 19$ 
33. Xu R, Chen J, Zhang X, Wang R, Xu S (2020): Heat Leakage Numerical Investigation of a Compound Parabolic Concentrator-Pulsating Heat Pipe Solar Collector. Journal of Thermal Science

34. Xu RJ, Zhang XH, Wang RX, Xu SH, Wang HS (2017): Experimental investigation of a solar collector integrated with a pulsating heat pipe and a compound parabolic concentrator. Energy Conversion and Management 148, 68-77

35. Zhang T, Cai J, Zheng W, Zhang Y, Meng Q (2021): Comparative and sensitive analysis of the annual performance between the conventional and the heat pipe PV/T systems. Case Studies in Thermal Engineering 28, 101380

\section{Figures}

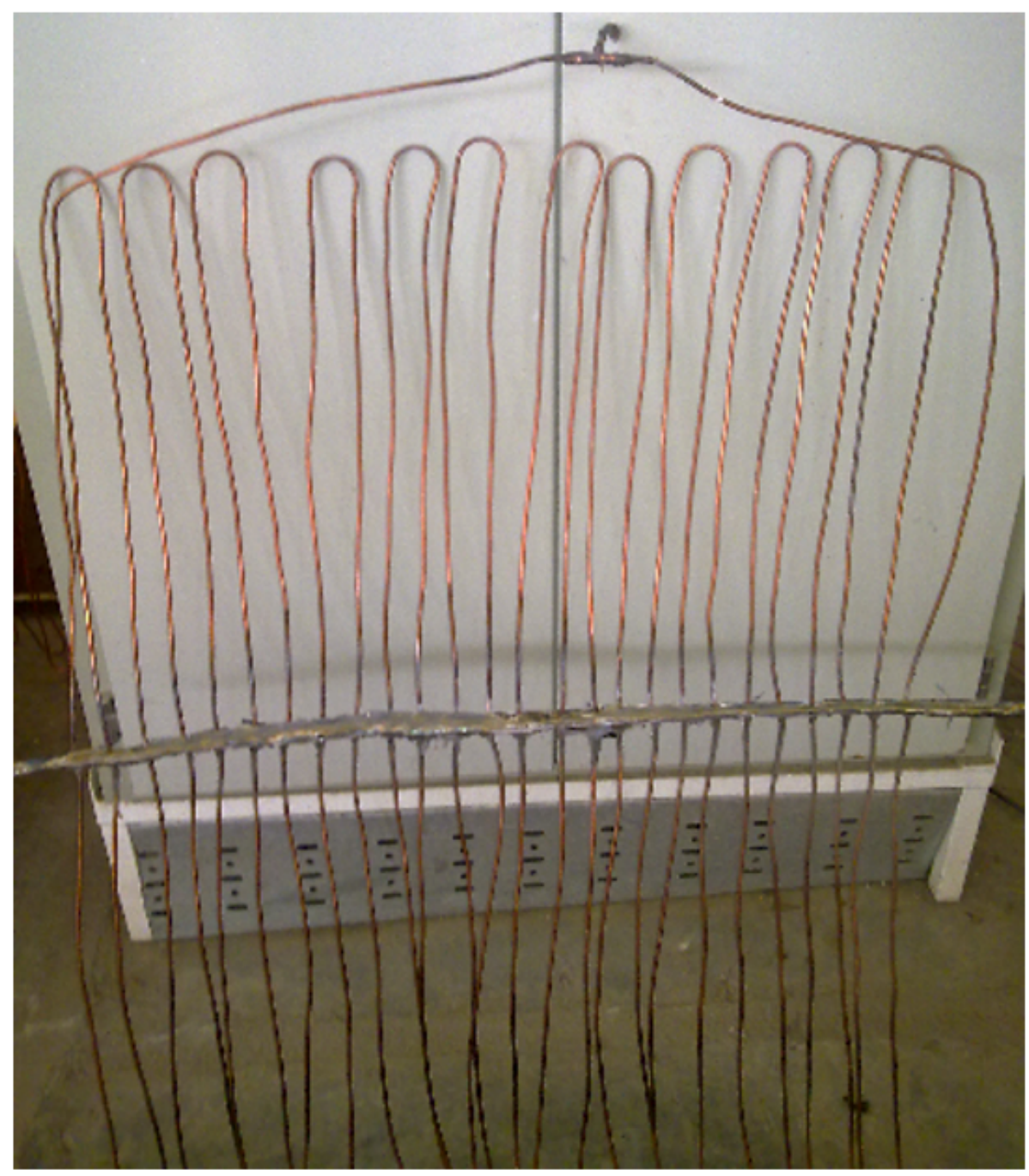

\section{Figure 1}

The fabricated pulsating heat pipe. 


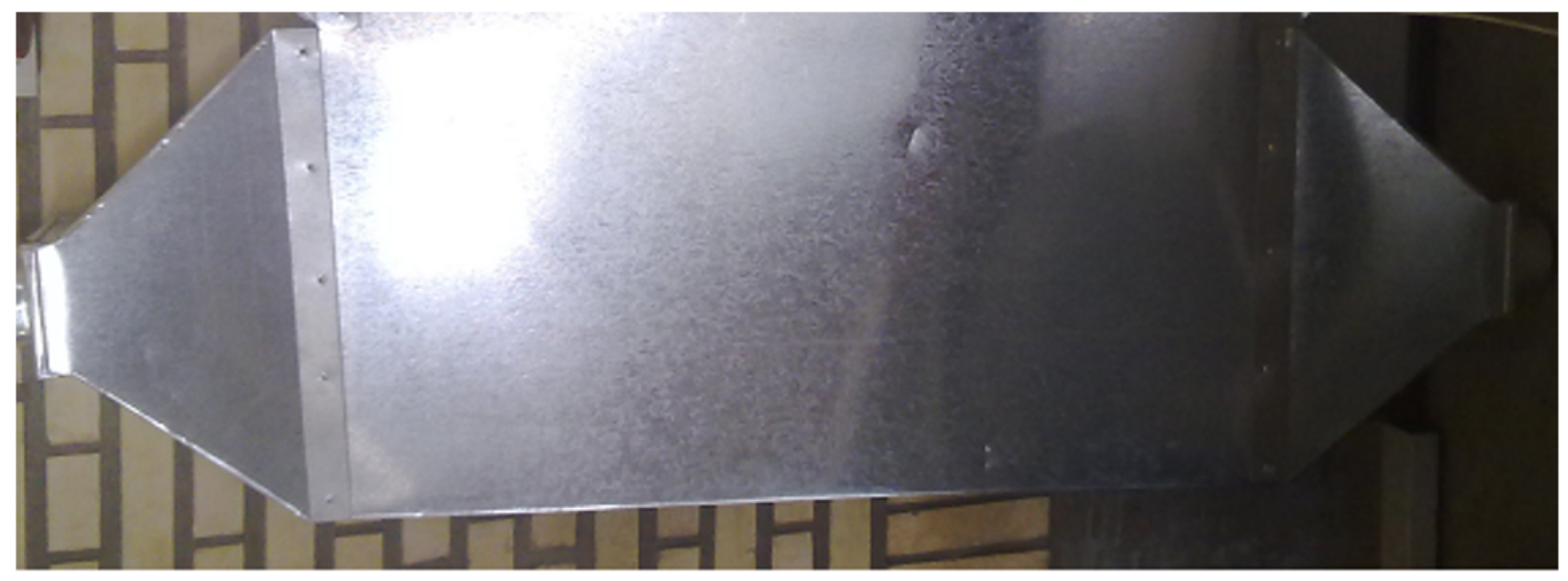

Figure 2

Exhaust air channel which the evaporators are placed inside.

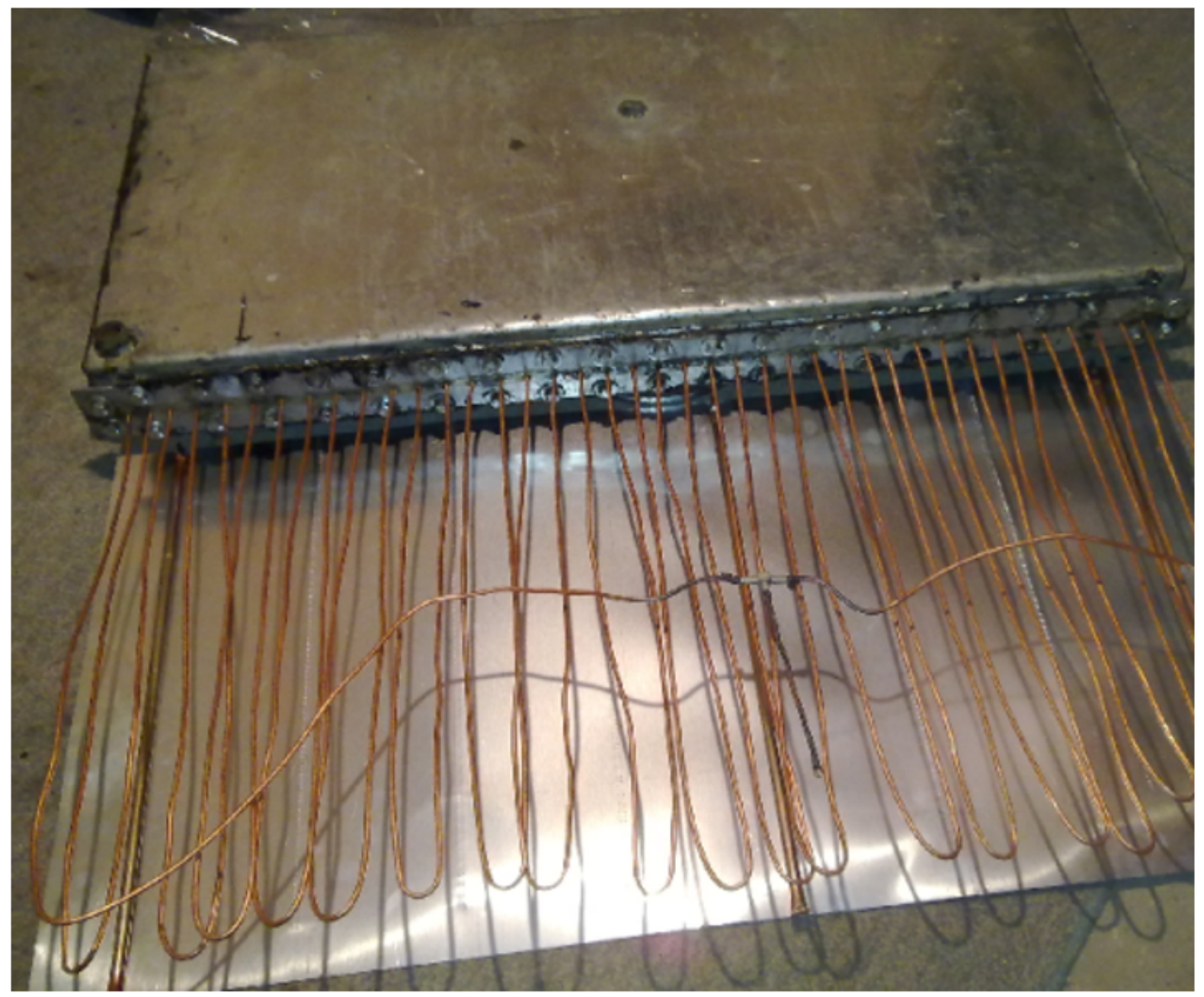

\section{Figure 3}

The water reservoir coupled with PHP. 


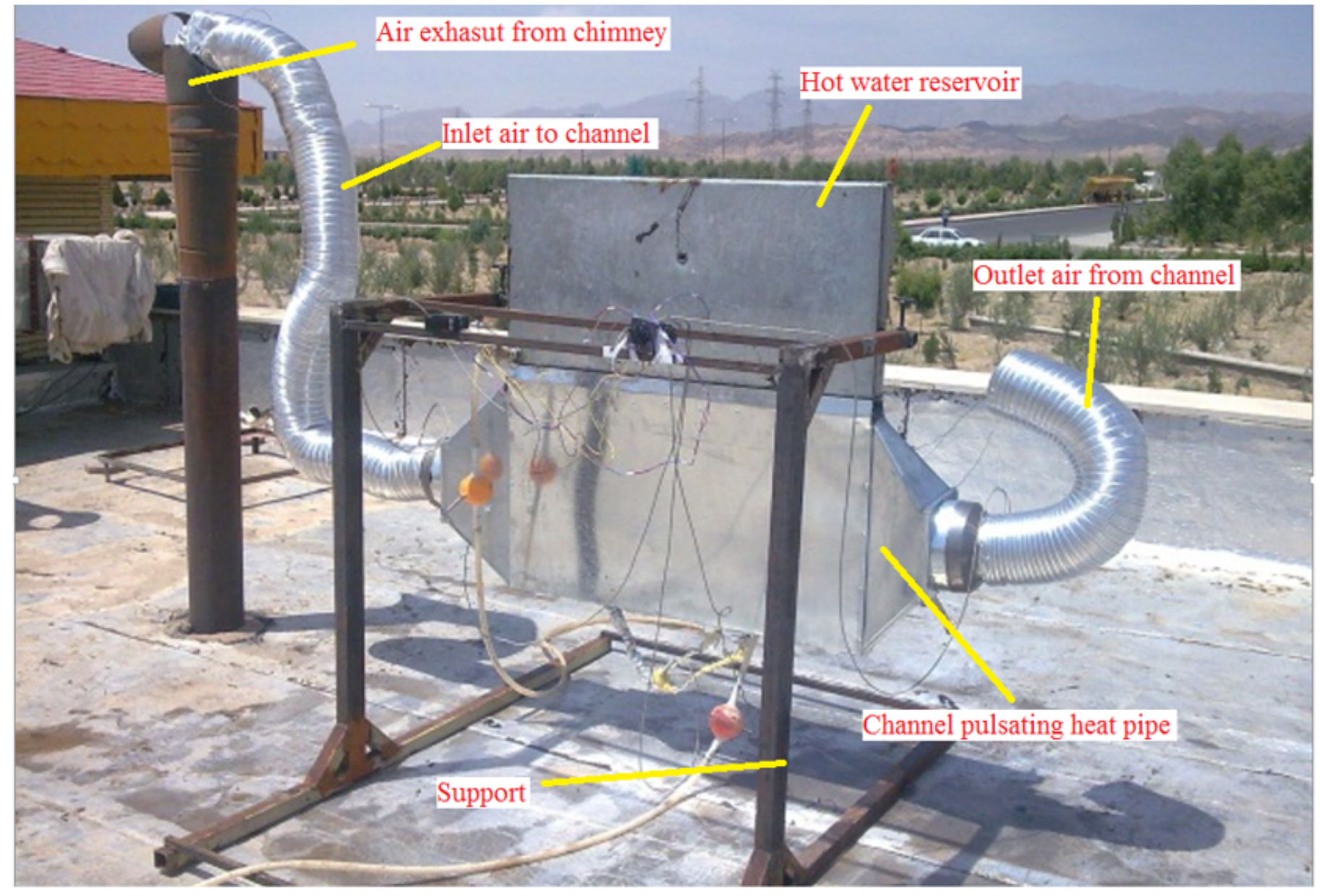

\section{Figure 4}

The experimental setup of heat recovery using PHP. 


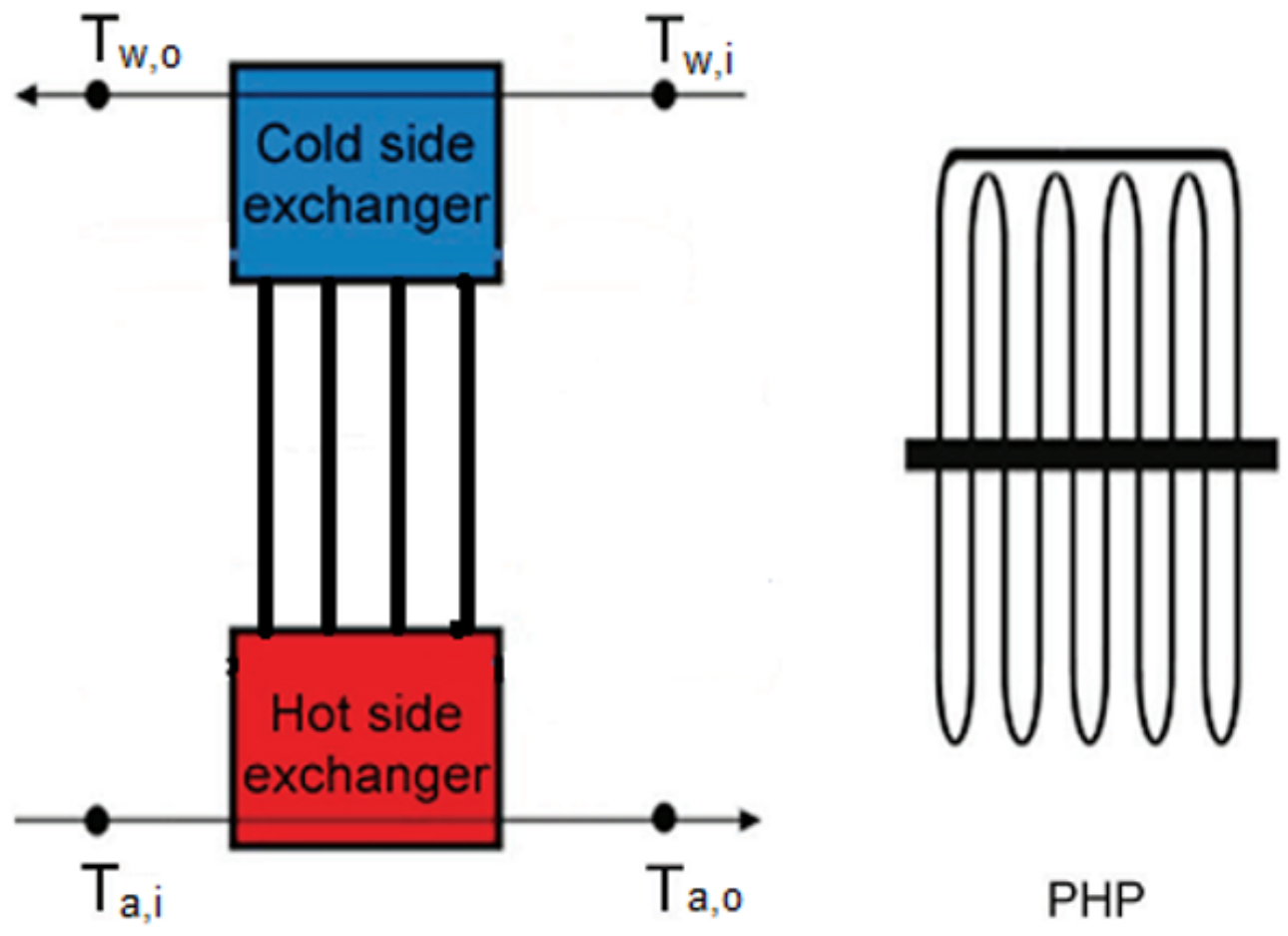

Figure 5

The schematic of pulsating heat pipe. 


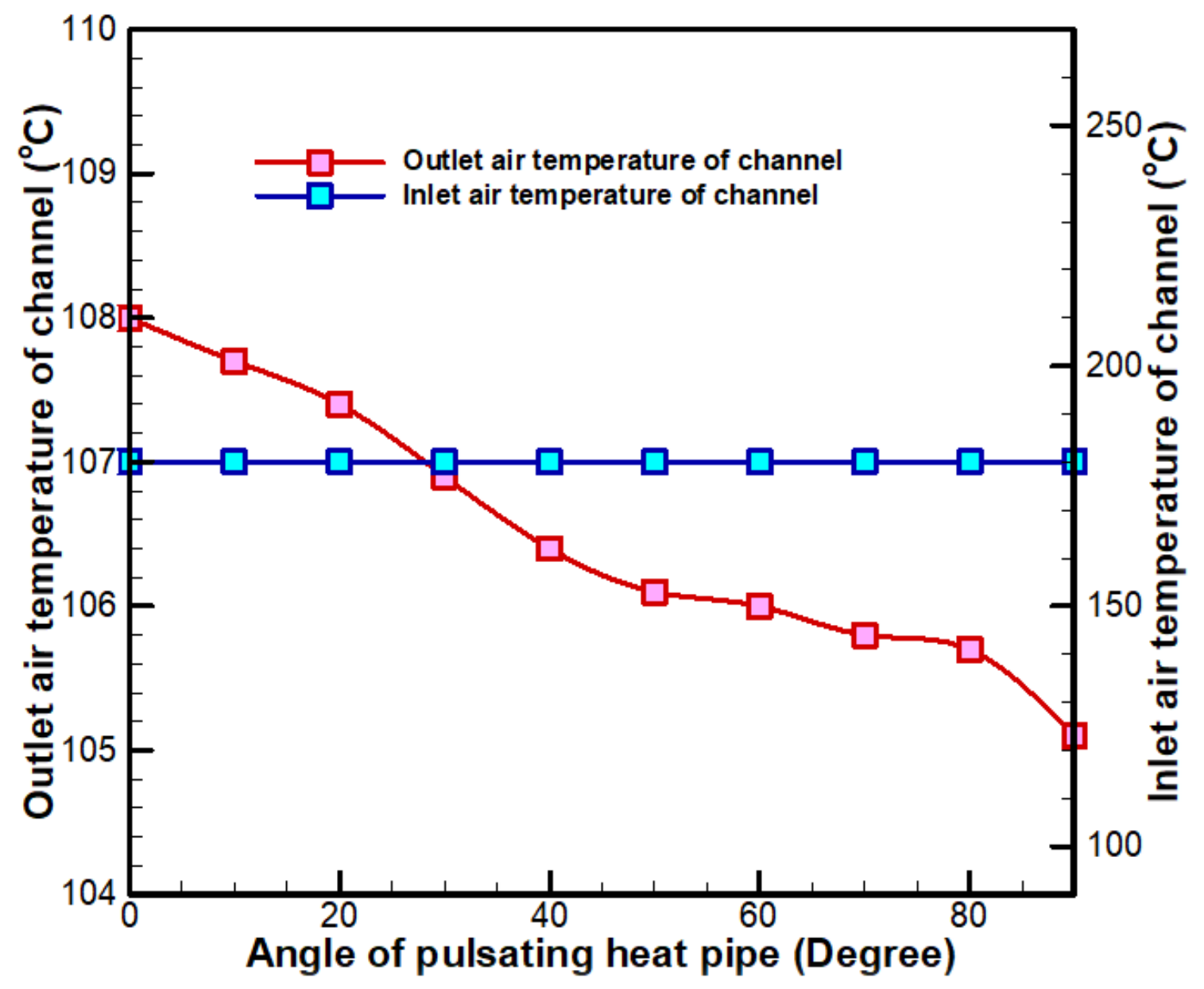

Figure 6

The inlet and outlet air from heat exchanger channel. 


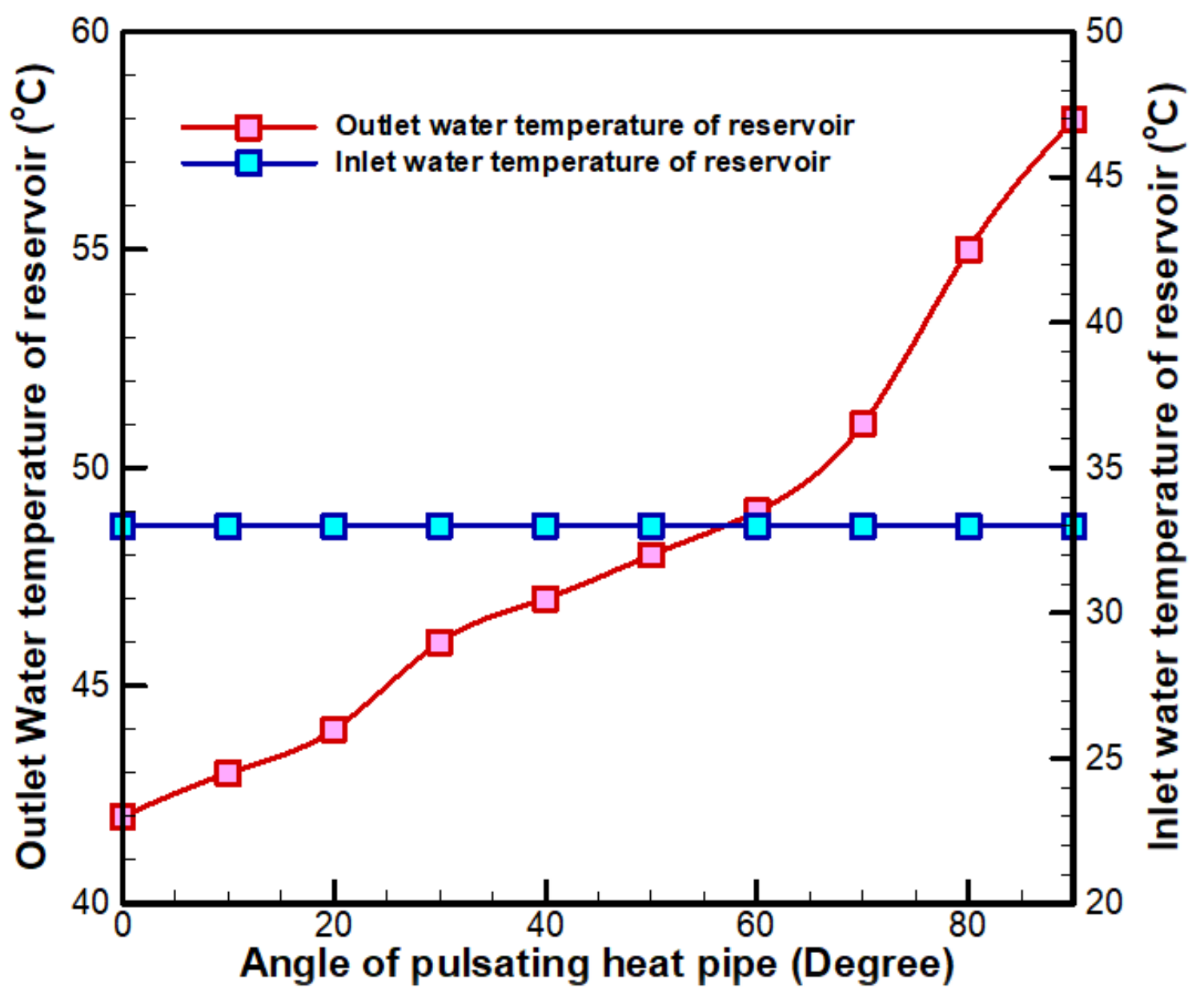

Figure 7

The inlet and outlet water temperature reservoir of the system. 


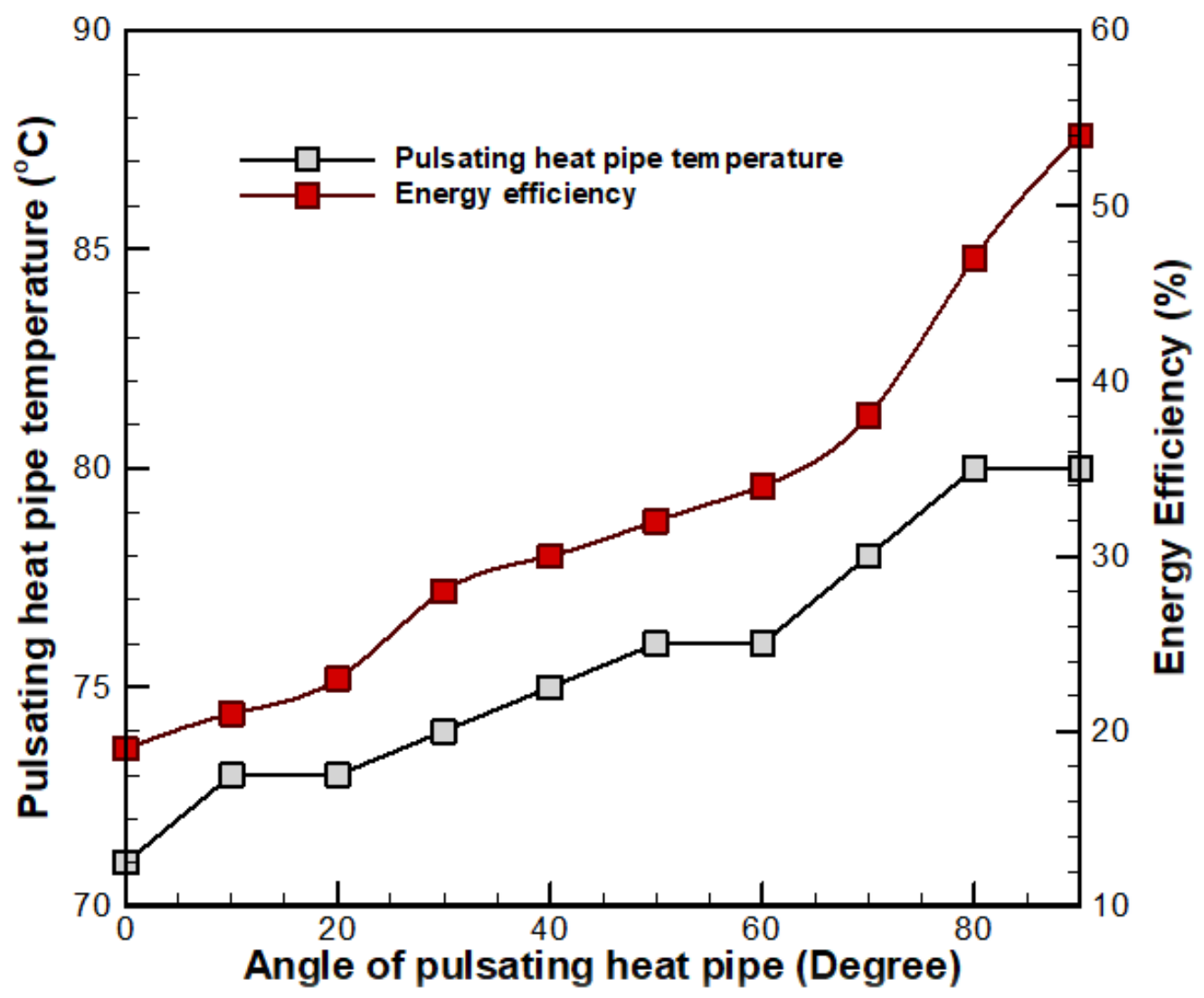

\section{Figure 8}

The energy efficiency and pulsating heat pipe temperature of the system. 


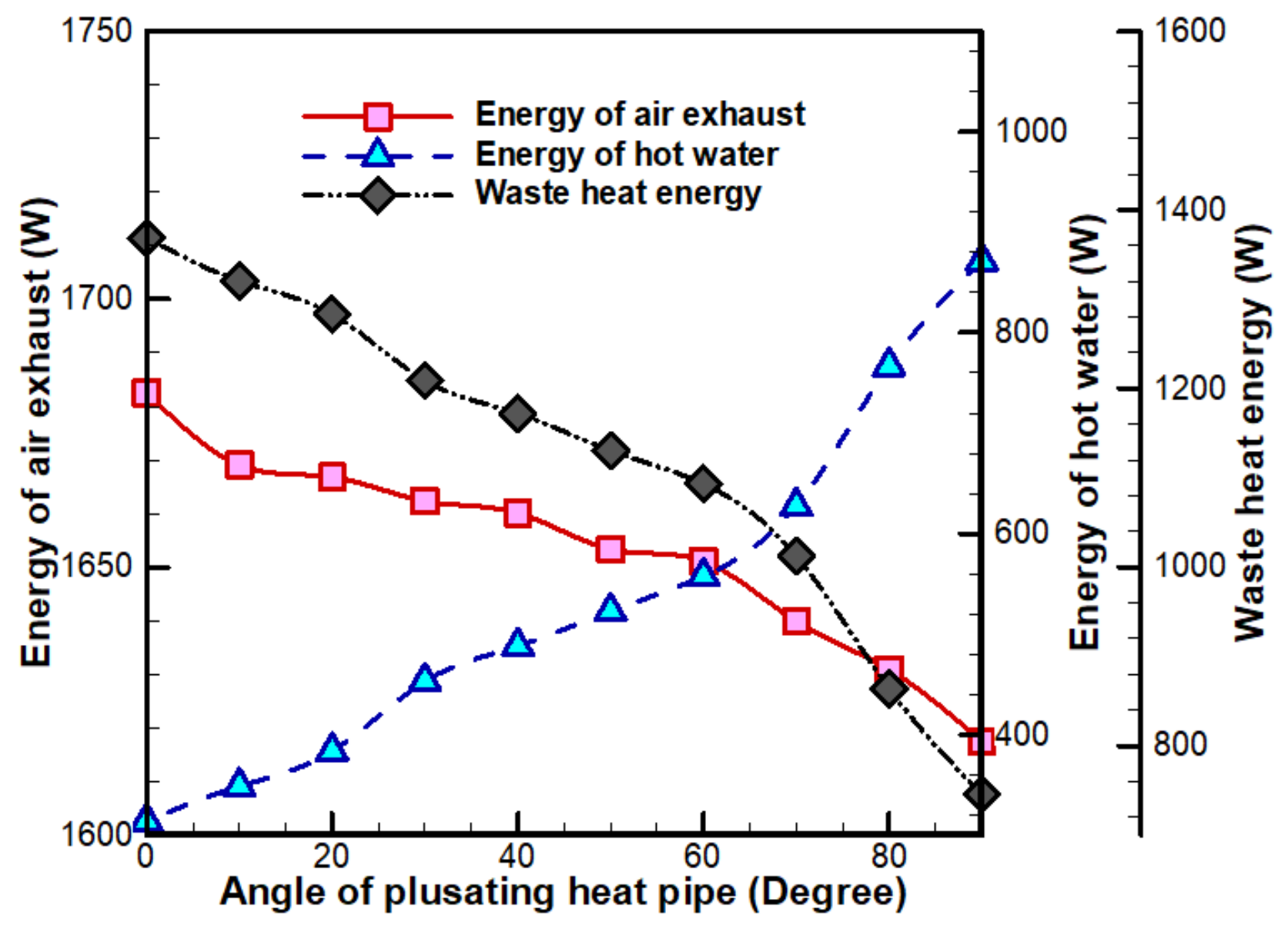

Figure 9

The energies of air exhaust, hot water and waste heat of the system. 